\title{
Discussion on the Coordinated Development and Innovation of National Music and Contemporary Multicultural Music Education
}

\author{
Guo Wei
}

\author{
College of Arts, Xiamen university, Xiamen, 361000
}

\begin{abstract}
Keywords: Multicultural music education, national music, innovation, development
\end{abstract}
\begin{abstract}
The existence of music culture determines that music education is a certain form of human music culture, while music education, as a certain form of music culture, acts against a certain musical culture, making music education a profound cultural and spiritual connotation, and music Education plays an important role in the inheritance and development of national music culture. Only when we pay more attention to the humanistic connotation of music education, can we put music education research in the background of music culture, and music education will have vitality. The function of multicultural music education is to give full play to the cultural inheritance function of music education, and make music education become a musical culture form with profound national background in the heritage of music culture. This article is based on the background of multicultural music education. In view of the present situation of China's national music inheritance and development, this paper analyzes the problems in the practice of national music teaching under the multicultural background and puts forward the corresponding solutions, at the same time,Let students know more about the basic characteristics of Chinese folk music and the outstanding national culture behind it.
\end{abstract}

\section{INTRODUCTION}

National music is a characteristic musical art form that can demonstrate national culture, which fully embodies the connotation and national spirit of national culture. With the development of history, under the sedimentation of history and culture, national music takes traditional music as its seed, and it is separated from traditional music. Music culture, as a cultural form of expressing human thought, is bound to be influenced by the traditional culture of our own nation and has distinct national characteristics. Based on inheriting the essence of tradition, a new musical form has been transfigured. Today's music has both poetic elements and contemporary style. With the rapid development of social economy, the 21 st century has entered a new era of new economy. Changes in the times have led to an increasingly diversified cultural need. This is both an opportunity and a challenge for music education in Chinese universities. Musical culture, as a concept shared by certain human groups, and musical activities, must be acquired by acquired, organized and purposeful musical education. Music education is a necessary condition for the formation and development of music culture. The understanding of various kinds of music based on different cultural concepts, the choice of teaching contents, the use of teaching methods, etc., will inevitably reflect the traditions, interests, and values of different national music cultures, and thus form a musical education with ethnic characteristics. Therefore, multicultural music education plays an important role in the transmission of national music culture.

\section{MULTICULTURAL MUSIC EDUCATION THEORY}

Multicultural music education is one of the hot issues in music education in the world today. It is a positive reflection of Western countries in the face of immigration issues, national conflicts, and international relations, and reflects the international trend of educational democratization. It is a long-lasting practice that brings a new musical value to music educators. There are many references to 
multicultural music education, such as the reference used in general education, "international relations in music," "multiracial music," etc. Most of these formulations have similar or derived meanings. Its main point is to emphasize that in a country's social background where multiple cultures coexist, allow and guarantee the equal development of all national groups' arts and cultures so as to enrich the education of the country's arts and culture. Today, "multicultural music education" has been widely accepted by the music education community. It involves a professor of music culture in a broad field of music. It focuses on the characteristics of the national culture, not the broader definition of multiculturalism that is accepted in today's education. At present, many experts and scholars in music education emphasize the teaching of music from a multicultural perspective. Topics discussed include the teaching of multicultural music in the classroom, the importance of the world outlook in music classification, and the need to learn different music cultures.

Development of multicultural music education both in China and abroad. Since the twentieth century, the development of multicultural music education in the world is in the confluence of two kinds of situation, one is the development of music education in developed countries, and the other is the rise of the awareness of multi cultural music education in developing countries. In the developed countries of Europe and America, the two forces of society and academia promote the development of multicultural music education, first of all from the serious and serious study of the non western music in the United States of higher learning in the United States and its achievements, that is, the recognition of the nature and value of human multicultural music. This confirmation comes from the history of the development of world music academic research in more than 100 years. It reveals the rich and colorful cultural resources of human beings, and makes music education turn from a single Western perspective to the global multicultural perspective. At the same time, many developed countries, such as the United States, the United Kingdom, Australia, France, and many other developed countries formed the diversity of national groups, and multicultural music education also reflected the response to social issues such as "racial problems", "civil rights movement", "good neighborliness and friendship".

On the other hand, in developing countries, such as Japan, Korea and China, many countries have begun to rise and implement multicultural education. For music education, this consciousness and measures include the awakening of local music culture consciousness and the attention to all countries and national music cultures in the world. In recent years, with the increase of China's reform and opening up, and the increase in economic and cultural exchanges with other countries, the concept of multicultural music education has been introduced into China, and more and more educators and researchers have paid more attention to it and gradually revealed the importance and significance of the reform of Chinese music education.

In short, multicultural music education has become the main theme of the world's music education. It is attracting the attention of governments of all countries and will certainly have an important impact on China's music education reform.

\section{CHARACTERISTICS OF NATIONAL MUSIC EDUCATION}

Music comes directly from language, tone and voice, which determines that the music representing national culture must be unified in one style to reflect the perfection and unity of the same national music culture. The characteristic of national music education is different from that of general music education. It is "national character", that is, the object of teaching and research is to represent the singing method and culture of the Chinese nation. The nationality of national music education includes at least two meanings:First of all, the singing method that we teach and study is not only the singing method with Chinese national characteristics, but also the singing method that the masses are fond of and easy to accept and disseminate. "National singing" should first be a Chinese characteristic singing method. Its emulation, singing, sound, luck and performance should draw the essence from traditional Chinese opera, musical art, rap art and national song minor. It should reflect the cohesion 
of the Chinese nation and the diligence, kindness, wisdom, and virtues of bravery of the working people. As a national music art, it belongs to the people. Its purpose is to serve the people and express the people's most simple thoughts and feelings. Therefore, its content and form should be derived from the masses and rich in the characteristics of the times. Its melody and sound should be pure and simple and easy to be loved and sung for ordinary people.

Secondly, the national music teaching should cover the diverse traditional national music culture and its singing characteristics in China. The long and splendid culture of the Chinese nation gave birth to unique musical arts. China has a rich treasure of national songs. Viewed from a horizontal perspective, the national songs of the 56 national groups are vast and have their own characteristics due to differences in the region, language, labor methods, living customs, and cultural backgrounds. This has also led to the formation of representative repertoires and singing methods.

With the development of the times, modern civilization has changed the living environment of traditional national songs, and the forms and methods of singing for national music have also changed. The concepts such as "The National Songs", "The School Singing", and so on came into being. The national music arts moved from the field and villages to the prosperous cities. From the production of labor songs to the silver screen, it eulogized the great changes of the motherland and people's patriotic sentiments. They praised the love between love, affection, friendship and sincere feelings among people. This form of national singing differs greatly from the traditional national impressions of people in terms of form and content. The boundaries of various singing methods are also increasingly blurred. Is it national singing? What is the nationality of it? The answer is yes. The connotation of the national music art is not only reflected in the vernacular singing of the dialect, the natural stage of the wild hills, and the unrestrained natural singing. But it is the amalgamation of national spirit and national emotion.

\section{RELATIONSHIP BETWEEN MULTICULTURAL MUSIC AND NATIONAL MUSIC TEACHING}

National music teaching is the premise and foundation of multicultural music education. Under the background of the internationalization of music education, many countries will regard how to prevent their traditional music culture from suffering from the impact and destruction of the multicultural tide as their unshirkable responsibility and mission, and strive to tap the advantages of their own culture, and strengthen the national music education based on native language culture and highlight the national characteristics of music education. Therefore, the nationalization of music education is the premise and basis for the diversification of music education.

For the lascivious populists, the baptism of accepting other peoples or foreign music with an open mind is undoubtedly an adventure, with the assimilation, weakening, or marginalization of other national music or foreign music. However, countless facts have long and eloquently proved that under the prevailing circumstances and general trends of multicultural exchanges, if appropriate attitudes and positions are maintained, coupled with effective measures, even if some foreign factors are incorporated into their national styles, nor will it endanger the dominance of the national music. After some time, foreign elements in the music of the nation will inevitably be digested and dissolved, and finally converge to the first trace.

Multicultural music education is the guarantee and perfection of national music teaching. While attaching importance to promoting the achievements of national music, we should also strive to explore and develop the values of multicultural music culture. Respecting the outstanding cultural heritage of countries and advocating the international perspective of music development has become a common understanding of sharing the outstanding achievements of the world's music culture. Among these, a comprehensive understanding of multiculturalism is an important prerequisite for achieving this consensus. With more and more people concerned and understanding of multiculturalism and its related theories, the research on multicultural music education has been deepened at home and abroad. 
The diversity of music education is the guarantee and perfection of the nationalization of music education, which has also been recognized more and more.Therefore, when we are engaged in the practice of national music teaching, we must also strengthen our comprehensive understanding of multiculturalism.

\section{PROBLEMS IN THE NATIONAL MUSIC EDUCATION}

Lack of nationality in music college curriculum. Throughout the whole country, music schools in major music academies have generally established bel canto music and national music majors, and later they have established popular music majors. Although the curriculum has a wide coverage, it involves various aspects such as political theory, cultural foundation, national music theory, western music theory, professional theory courses, and so on, which reflects the school's emphasis on the overall quality of students. However, it is not difficult to see that the above curriculum setting does not highlight its professional characteristics for students of national music majors, and is specifically expressed in the following two aspects:

Insufficient attention to traditional national music theory. National music education shoulders the important mission of inheriting our national music culture. China's rich and colorful national music culture is an inexhaustible source. It is hard to imagine how we can cultivate outstanding national music or other national music practitioners without the traditional culture and language of national music. Since the reform and opening up, the national music students who live on the urban campus are under the influence of the social environment. They are pursuing fashion but lacking tradition. They emphasize book knowledge and lack life experience. They also know little about national culture. All these require schools to give sufficient attention to the theoretical knowledge of national music and culture in the curriculum.

The school has not given enough attention to the course setting. In the setting of the basic course of the compulsory course, the music theory class "sight singing", "ear", "music", "harmony" and "musical form" were set up, but they were not involved in "Chinese traditional music" and "national music theory"; the basic skills "Piano"were set up, while the lesson of Chinese traditional instrumental music is not involved in the class. In the language courses, the courses of Italian, German and standard Mandarin have been set up for each semester, but the characteristics and laws of the local dialects in China are not involved. It is worth mentioning that in the first grade of the first and next semester, the "national song" and "opera" are set up respectively, which is a very important basic course for all vocal students. In the course of "national songs", the basic theoretical knowledge of national songs and the classical traditional national songs are involved in the teaching of singing. In the course of the opera, the singing teaching of classical opera, which is mainly based on Beijing opera, has played an indispensable role in broadening the students' vision and understanding the vast traditional music culture of our country. It is not enough for the students of national music major because of their short time and limited knowledge, and teachers can only choose the most classic and familiar works and the most basic theoretical knowledge.

Insufficient attention to worldwide national music theory. In the 21 st century, we are faced with a world of economic integration, political multipolarity, and cultural diversity. What we need to cultivate are highly qualified people who understand and respect the music cultures of various nationalities in the world and have good cultural values. Therefore, as a higher music institution that cultivates talents for music, we must first guide students to understand and understand the music cultures of all national groups in the world.

Although Chinese music schools have a wide range of courses involved in elective courses, including Chinese traditional music, classical poetry, music psychology, writing, and so on, it is a good supplement to the shortcomings of compulsory courses. However, in terms of its contents, it can be divided into Chinese traditional music culture, western music culture and world national music culture. Among them, the world national music culture has only one course. Elective courses are 
selected by students according to their interest and time. Some students may have never been in contact with this course through the four years university life. From this case, we can see that the current curricula of national music education ignore the traditional music culture of our country and the cultures of all national groups in the world outside the western music culture.

The teaching system lacks a complete training model. There are fifty-six nationalities in China. Each nation has its own rich national music culture and excellent local national songs. However, in the current teaching of national music, the music college of our country does not formulate reasonable teaching methods and examination evaluation system for the students' nationality and their personal style and characteristics, and does not form a complete training mode, which leads to the restriction of the students' individualized and diversified development. This kind of malpractice is manifested in the following aspects.

Firstly, the lack of research on the scientific nature of traditional Chinese national music also limits the development of national music education to a certain extent. In the teaching of national music, when it comes to "scientific methods", we often apply western music theory. Indeed, the theory is very scientific. Indeed it is worth learning and learning from us. On the other hand, on the other hand, we do not doubt that the traditional Chinese national music is not scientific. In fact, there are many reasonable and scientific things in Chinese traditional national music. The problem is the lack of research and the rise of its extremely rich form of music to scientific theory.

It has been half a century since national music education was included in the scope of higher education. However, a unified syllabus and national music textbooks have not yet been compiled. At present, the national music syllabus in music academies is generally written by teachers with experienced school organizations. From the content point of view, the emphasis is first placed on the learning and mastery of modern "scientific" skills, and on the other hand, the use of teaching materials is relatively arbitrary, which is usually ordered by the school itself, and the teacher selects and supplements the teaching materials according to the needs of the teaching.

Secondly, is the lack of a reasonable teaching evaluation system, when students enter the school, some students have formed their own personalities because of the differences in the regions, nationalities, and individuals. In the current teaching evaluation system, the students' personality is flattened. In professional examinations, teachers generally choose songs for students, and for national music students, there is no specific requirement on which style of work must be mastered at which stage of study.

\section{THE PRACTICE OF NATIONAL MUSIC EDUCATION UNDER MULTICULTURAL MUSIC EDUCATION}

Establishing the concept of equality of music values among all national groups. The concept of multicultural education came about in the 1960s, and it began to flourish in the 1970s. Its main idea is to allow and guarantee the equal development of the arts and cultures of all national groups in the national social context in which multiple cultures and national groups coexist, thus to enrich the culture and education of the entire country, and hope that students understand the complexity of culture and respect their own and others' culture.

The multicultural trend of thought has influenced the development of music education. It is the new trend of music education in the world and the main melody of music education in twenty-first Century. It has attracted the attention of all the governments and music educators, including China. In 2001, China's Ministry of education formulated and promulgated the "art curriculum standard". The proposition of "understanding multiculturalism" in new educational philosophy puts forward new requirements for our educational concept and knowledge and skills. The art curriculum standard emphasizes that while emphasizing and carrying forward the national art, we should also learn, understand and respect the culture and art of other countries and nationalities in the world with a broad vision, and make students establish equal multicultural values through learning. The 
promulgation of the standard not only indicates the direction of the education ideas and teaching methods of Chinese art education, but also brings great opportunities and challenges to the art workers. In the background of the Chinese music education system established by the western music education system, the professional national music education in China has been developed and developed. In the vigorous development of modern national music, its single Western cultural field of vision has also brought national music education to cultivate students' singing style and method pattern. Therefore, the national music education in the new period should renew educational ideas, change teaching ideas, completely abandon the concept of monism, carry out multicultural education in the students and set up the concept of equal value of all national music.

Enhance understanding of music arts of all national groups in the world. Our national music education lacks the diversity of musical styles. The development of national music education should be based on the excellent traditional music culture of our nation. At the same time, we should draw on the nutrients of the music and culture of all the nations of the world.

Strengthen the national music course construction. It includes national music culture, national music theory and national music performance curriculum. In order to enrich and strengthen the curriculum of national music culture, the course of "Chinese music history", "national music culture", "introduction of national music" (including minority music), "Chinese instrumental music" and "traditional national vocal music theory" are included in the required courses so as to improve the students' national music cultural quality and cultivate the students' nationality music thinking. The construction of the basic bilingual music curriculum is to set up the existing western professional basic courses such as "sight singing", "ear", "harmony", "Qu style" and the construction of Chinese traditional professional basic courses, and to set up "Chinese traditional music" and "national musical style research" as a required course, in order to make the students understand and express national music culture in context of mother grammar and language. To enrich the course of national music performance, including "folk song", "opera listening and singing", "rap art" and other courses, can be opened in required courses and elective courses according to the actual situation of the school. In the teaching process, we should include professor of theoretical knowledge about the emergence and development of traditional music art.

Teachers shall have high comprehensive cultural qualities. Higher comprehensive cultural literacy is essential for national music teachers. Without a better cultural quality, it is impossible to fully understand the connotation of music works, and it is even impossible for students to fully understand their works. Diversified national music teaching requires teachers to have a wide range of knowledge and strong professional skills. In the face of the diversified teaching links, such as collective class, public class and practice class, we must make every student learn and master the basic knowledge and skills in the music, and set up a correct sound concept. Therefore, teachers not only require a strong professional level, profound theoretical attainments, but also have high comprehensive cultural attainments, as much as possible to understand some related subject knowledge, such as literature, art, drama, film and television, so as to make the arts intersecting, and constantly enrich and improve their multicultural values.

\section{THE ROLE OF MULTICULTURAL MUSIC EDUCATION IN THE COORDINATED DEVELOPMENT AND INNOVATION OF NATIONAL MUSIC}

Multicultural music education promotes the development of the national music culture. In the process of transmitting, inheriting, accumulating, creating, and updating the human music culture, new musical cultural factors have emerged. Therefore, the change of music culture becomes an indisputable fact. Communication plays a decisive role in the changes of music culture. It makes music culture flow between society and society, regions and regions. The spread of music culture needs to have a certain transmission route, communication method, and communication medium. Music education has unique advantages in these aspects: Music education has the function of 
selecting and organizing the content of the dissemination, so that the core content of the music culture can be disseminated; receiving feedback information in the process of music education, correcting the transmission channels and content, ensuring the authenticity of the music culture dissemination; using all possible educational means to maximize the scope of dissemination; using "optimized" teaching methods to make the recipients easy to accept, so that the transmitter and the receiver can establish a good and stable relationship.

Innovation is another important dimension of the inheritance and change of music culture. The process of music education can be regarded as the creation process of musical culture in a sense. The difference between the physical and mental state of the educator and the instructor makes the process of music education not simply replicate the music culture of predecessors, but to merge, gather local music culture and foreign music culture, which derive new elements of music culture, give new meaning to music culture, and cultivate innovative talents for the development of music culture. For example, the famous musician of our country, Liu Tianhua, used the violin techniques and Western musical forms to create excellent erhu works ("Guangming" etc.), and made an effective reference to the violin Etudes in the erhu course. Now, many of the erhu music created by Liu Tianhua has already become a classic of Chinese music culture treasure house, and it is a popular music. His erhu teaching method is widely used in the erhu teaching in professional music colleges and trained a large number of excellent erhu performers. Liu Tianhua's effective reference and valuable exploration to the foreign music culture has produced a new tradition of Chinese music culture and made an important contribution to the development of the music culture of the nation.

In the course of the inheritance and change of music culture, music education can not only promote the reference and integration of music culture, but also obstruct the communication between music cultures. It can not only improve the vicissitude of music culture, but also result in the loss of the national music culture because of the blind pursuit of innovation by the educated, resulting in the exhaustion of the source of music culture creation. It can not only promote the development of the music culture of the nation, but also disregard the local music culture and cause the "lag" of the development of national music culture because of the educator's worship to the spirit of foreign music culture, standard and technology, diffusion and dissemination of the elements make it a "mass music education" for all the people, and can also be limited to a few people and become "music elite education" for a few people. Music education is such a positive and negative feature that provides a theoretical research focus for music education. If one ignores the negative effects that music education may have on the changes and inheritance of music culture, one-sided exaggeration of its positive effects will make music education deviate from the correct direction and hinder the inheritance and development of music culture. Multicultural music education should effectively and reasonably learn from and disseminate foreign music culture, so as to truly play its role in promoting the inheritance and development of the national music culture.

Multicultural music education is the main channel for the inheritance and development of national musical culture. Music culture also exists in social life. In the work life and folk custom activities, the working people amuse themselves through music. Therefore, the unconsciousness of Music Education (such as environmental edification, folk activities, social music and cultural activities, etc.) is one of the ways to make traditional music culture can be passed down from generation to generation. However, the conscious and purposeful music education is the most important tradition, experience and skill in the music culture. It can make the educator get the maximum system knowledge in a short time. Therefore, the multicultural music education is the main channel for the inheritance and development of the national music culture. Its advantage is: it has a high degree of generality that it delivers to people. These contents constitute the basic core of the music culture, and make the posterity highly adaptable to the music culture created by the predecessors, thus preserving the systematicness of the music culture tradition and ensuring relative stability of the continuity and transmission of different music cultures with national style. Therefore, music education, as an indispensable tool for music culture to be regenerated and propagate, has become one of the necessary 
means for the transmission and development of music culture. The preservation of musical culture and the maintenance of musical culture is one of the basic functions of multicultural music education.

However, music education preserves and maintains music culture by selecting, organizing, and transmitting music culture. In general, the choice and arrangement of music education in music education is based on two important factors: social needs and the psychological development level and age characteristics of the educated. The music and cultural content that meets the needs of the society and the psychological status of the educated have become an integral part of the music education system. The music and cultural elements that do not meet the needs of social development and do not meet the psychological conditions of the educated are rejected and weakened. For example, in the history of music and culture in China, several music symbols such as work spectrum, score reduction, notation, and stave were used to record music. With the development of society, the notation and the notation of notation of the staff are more suitable to meet the general needs of the development of social music and cultural activities, and thus have become the main teaching contents of the learning notation in music education, and the rest of the notations of all kinds are gradually being neglected. It can thus be seen that the elements of music culture selected and organized by music education, that is, the content taught in music education, are also the most important and core parts of the treasure house of human music, and to a certain extent, it reflects the style of a national music culture., characteristics and spiritual connotation are the essence of human music culture treasure house. The basic function of music education is to reconstruct the content of music culture and transfer it in the most acceptable way for educators to grasp as much knowledge as possible in the shortest possible time and then master the main body of music, to ensure the unity and integrity of the music culture system heritage. The reform of all kinds of music teaching methods is also generally centered on this basic function. As an ever-evolving cultural phenomenon, music culture is a kind of accumulative thing. It is transmitted through music education and left to the next generation. Therefore, the inheritance function of music education makes music culture inherited and regenerated, and music education itself has become the reason for the existence of music culture.

Multicultural music education enhances cultural cohesion. No matter what culture is, to some extent, it is integrated into one. Because of the development of social politics and economy, the culture that is suitable for them is needed. The development of the society depends on education. As an important part of the music culture, music education is only integrated into the society and can be developed in the overall development of science, technology, economy and society. Reaching a music culture be built around the social politics and economy and form a harmonious music culture with Chinese national cohesion and national connotation. People in the music education activities establish correct music values and influences with good feelings, thus sharing a music culture and gaining a sense of identity. Due to the differences in the languages of various nationalities in the world, the differences in language tones have resulted in the formation of musical basic materials, basic means, and basic techniques used by different nations for music performance (eg scales, melody, tune, circling, etc.). ), resulting in the diversity of ethnic music styles. Some people call the "music style" simply "musical style" and others "phonic" and "spirit". It is precisely the existence of "Lok Feng", "phonology" and "dramatic charm" that all ethnic groups in the world have a musical culture that symbolizes their own ethnic attributes, and musical styles have become the identification criteria for ethnic identity of musical works. For example, the music, written in the tone of the Korean nationality, plays it with the special music techniques of the Korean nationality. It has the Korean style and represents the Korean music culture. The Korean people get a sense of identity from a shared music culture; instead of Korean composers, the Korean style music works with Korean style and the music works of Korean style are used by the performers, which have become a part of the Korean music culture accumulation. The characteristics of music and culture belong to the Korean nationality. In addition, the theme of the famous violin concerto "Liang Zhu" is to use our country's Yue opera as the material, and the music adopts the basic means of Chinese opera's scattered plate and rocking plate. Violinist Yu Lina uses a lot of Chinese special tone embellish in this concerto. This method is applied 
to the performance of the Liangzhu Violin Concerto. Therefore, although the musical instruments used in this music are foreign and the compositions of the works are foreign, the existence of their Chinese "music", "phonology" and "Rhyme" makes people think that the "Liang Zhu" is "Chinese" rather than "foreign".

The success of the creation and re creation of the concerto of the violin concerto is not accidental. It is directly related to the edification of the composer He Zhanhao, Chen steel and the performer Yu Lina in the great background of Chinese culture and the formation of the values of pluralistic music education. Therefore, in modern music education, the ancient oral and oral teaching forms, as well as the edification of folk culture environment, still have important research significance and exploration value for multicultural music education. Because multicultural music education is still an indispensable part of modern music education, we realize that it is impossible to understand the integrity of the music culture, and the music education can not be understood.

\section{SUMMARY}

The existence of music culture determines that music education is a certain form of human music culture, while music education, as a certain form of music culture, acts against a certain musical culture and embodies the profound cultural and spiritual connotation of music education itself. It is the trend of Chinese music culture to critically inherit the tradition of music culture and fully embody the spirit of the times, based on the country and the world. Therefore, only to put music education research into the great background of music culture has vitality. Only by giving more attention to the humanistic connotation of music education can music education become a musical culture form with profound national background in the heritage of music culture. The role of multicultural music education is to make students identify with the connotation of the philosophy of music education: there is a different but equally excellent music culture in the world. To give full play to the cultural heritage of music education, to practice multicultural music education and to promote the development of the music culture of the nation, the cultural value of music education can be realized in an all-round way.

\section{REFERENCES}

[1] Zheng Baohua, Wang Gang. Analysis of the Development of Multiculturalism in Contemporary Art Education[J]. Chinese Music, 2007, (4): 220-226.

[2] Yang Shuguang. Professional National Vocal Music Education in the View of Multidimensional Culture[J]. Chinese Music, 2004, (2): 93-96.

[3] Deng Lan. The problems of Multicultural Music Education in Our Country and Their Solutions[J]. Journal of Xiangnan University, 2004, 25(1):92-94.

[4] Liu Yuan. The Vocal Music Teaching Mode for Normal Colleges Facing the New Century[J]. Chinese Music, 2007, (3): 190-192.

[5] David J. Elliott. Music Matter: A New Philosophy of Music Education. New York: Oxford University Press, 1995: 35-38

[6] Zhu Yujiang. On The Shift of Focus of Contemporary Music Education[J]. Journal of Nantong University (Education Science Edition), 2005(3): 90

[7] Chen Yaxian. The Role of Multicultural Music Education in the Inheritance of Ethnic Musical Culture[J]. Fujian: Journal of Fujian Normal University (Philosophy and Social Science Edition), 2006: 48 
[8] David Elliot. Concerned about Music Practice - The Philosophy of New Music Education[M]: Xie Jiaxing and other translations. Shanghai Music Publishing House, 2009.55 